\title{
CHEMICAL ANALYSIS OF MACROPHYTE (CYPERUSALTERNIFOLIUS) GROWING IN SURFACE FLOW CONSTRUCTED WETLAND (SFCW) FOR WASTEWATER TREATMENT
}

\author{
Luna Al-Hadidi ${ }^{1}$, Amer Sweity ${ }^{2 \square}$ \\ 1,2 National Agricultural Research Center, P.O. Box 639, Baqa'a 19381, Jordan
}

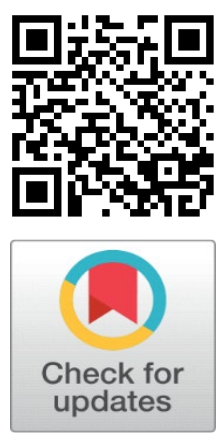

Received 07 January 2022

Accepted 18 February 2022

Published 03 March 2022

\section{CorrespondingAuthor}

Amer Sweity,

amersweity@narc.gov.jo

DOI

10.29121/granthaalayah.v10.i2.2022 .4506

Funding: This research received no specific grant from any funding agency in the public, commercial, or not-for-profit sectors.

Copyright: (C) 2022 The Author(s). This is an open access article distributed under the terms of the Creative Commons Attribution License, which permits unrestricted use, distribution, and reproduction in any medium, provided the original author and source are credited.

\section{ABSTRACT}

We examined the chemical contents of Cyperusalternifolius growing in surface flow constructed wetlands (SFCW) used in the treatment of partially treated wastewater. The (SFCW) wetland is composed of three cells in series of which two are open water surfaces and one is a channel bed planted with Cyperusalternifolius was designed and constructed. Four different mixtures of treated wastewater TWW effluent and the primary TWW effluent were used under different hydraulic retention times (HRT) of 3, 6, 9, and 12 days within the (SFCW) wetland. Higher accumulation of nitrogen $\mathrm{N}$ was detected in the plant's parts in an order magnitude of leaves $>$ stem $>$ rhizome $>$ root. Pronounced increase in potassium $\mathrm{K}$ concentration at the rhizome and stem was detected, while high amount of manganese $\mathrm{Mn}$ was accumulated in leaves. Roots and rhizomes were the main sinks for zinc $\mathrm{Zn}$ and phosphorus $\mathrm{P}$.

Keywords: Constructed Wetlands, Cyperusalternifolius, Water Treatment, Macrophytes

\section{INTRODUCTION}

Constructed free water surface (SFCW) wetlands are low-cost artificial wastewater treatment technology composed of one or more treatment cells in a building design Davis (1995). It is also known as surface flow wetlands closely mimicking natural wetlands in appearance as they comprise aquatic plants that are rooted in a soil layer on the bottom of the wetland and water flows through the leaves and stems of plants Vymazal (2001). Constructed wetlands can be used as the main unit process in a system to treat municipal wastewater Sundaravadivel et al. (2001). While some degree of pre-or post-treatment will be required in conjunction with the wetland to treat wastewater to meet reuse requirements, the wetland will be the central treatment component. Constructed wetlands technology can be used in combination with other secondary treatment technologies Vymazal et al. (2006). A constructed wetland could be placed upstream in the treatment train to optimize the cost of secondary treatment. In other uses, constructed wetlands could discharge secondary effluent to other enhancement wetlands for polishing Davis (1995). The constructed wetlands can provide secondary treatment for higher-strength municipal wastewater and treat it to secondary effluent standards and better. Wetland plants create a good environment that supports a wide range of physical, chemical, and microbial processes. These processes separately and in combination remove total suspended solids (TSS), reduce the. influent biochemical oxygen demand (BOD), transform nitrogen species, provide storage for metals, cycle phosphorus, and 
attenuate organisms of public health significance Hammer (2020). Due to sufficient water, wetlands are considered home to a variety of microbial and plant species Kadlec and Wallace (2008). The presence of macrophytes in the wetlands is one of the most obvious features and their presence allows differentiating wetlands from other unplanted soil filters or lagoons Vymazal and Kröpfelová (2008). Wetlands are home to a diverse group of plants, including emergent, floating, and submerged species. In general, only emergent macrophytes are specified for wastewater treatment wetlands as their occurrence and distribution are easily managed Brix (2003). Wetland vegetation assimilates minerals and nutrients into plant biomass and oxygenates the substrate in the vicinity of the plant rootTanner (1996). Macrophytes have a great tendency to remove pollutants by assimilating them into their tissue and providing surfaces and a suitable environment for microorganisms to transform the nutrients and decrease their concentrations Healy et al. (2007). Persistent emergent plants are among the most often used plants in constructed wetlands. One of the most common plants used in constructed wetlands is Cyperusalternifolius, it is a multiyear old plant that can tolerate extreme wastewater and can grow in humid soil Kyambadde et al. (2004). It is well known that not all emergent wetland species are proper for wastewater treatment since plants for treatment wetlands must have the ability to tolerate and withstand high salinity, flooding, and exposure to high pollutants water Stottmeister et al. (2003), Tanner (1996). Most wetland plants are adapted to survive in very saturated conditions. While most plants absorb oxygen through their roots, wetland plants can also absorb oxygen through their stems and leaves and transport it to their roots through specialized root cells Tanner (1996). Vegetation plays a significant role in constructed wetlands, especially on nitrogen and phosphorus removal. In this research chemical analysis of SFCW Wetland macrophyte (Cyperus alternifolius) was examined.

\section{MATERIALS AND METHODS 2.1. STUDY AREA}

Field experiments were conducted at the National Agricultural Research (NARC) research station at Ramtha in the northern part of Jordan. The experimental site is located near the Ramtha wastewater treatment plant, where irrigation with treated wastewater is highly practiced. The climatic conditions of the study area are characterized by cold winter with an average temperature of $9 \mathrm{C}^{\circ}$ and hot summer with an average temperature of $24.5 \mathrm{C}^{\circ}$ and an average annual rainfall of $275 \mathrm{~mm}$.

\subsection{SITE CONSTRUCTION AND PREPARATION OF SFCW}

The area allocated for the construction of the wetlands was approximately 25 $\mathrm{m}$ in width by $125 \mathrm{~m}$ in length. The site was shaped and graded using natural gravity. A survey was carried out using the "level instrument" to check for the natural slope of the site and determine the cut and fill areas. The surface wetland was designed using the multi-cell, multistage approach with different water levels at each cell as the water flows across the wetland (Figure 1). The advantage of the design is that it provides good flow distribution, thus maximizing shallow areas required for the successful growth of the macrophyte used and facilitating a more cost-effective maintenance program. In constructing the free surface wetland, the flow path was divided into a series of zones perpendicular to the flow path similar to those observed in natural wetlands. In general, the longer the flow path the closer flow patterns approximate plug flow Kyambadde et al. (2004). FWS cells length to width ratios is recommended to be in the range of 2:1 to 5:1 Crites (1994). Flow into 
and through the system is controlled by gravity. The free water surface wetland cells were configured in series to minimize short-circuiting and subsequently, leading to better overall treatment in the system. The first cell was an open water zone consisting of two cells configured in a parallel sequence to maintain flexibility and redundancy in operation. It is of a rectangular shape and is used as a retention basin with an aspect ratio of 2:1 length to width (L: W) and a total depth of $120 \mathrm{~cm}$. The depth of the soil media is $30 \mathrm{~cm}$ and $20 \mathrm{~cm}$ are left as a freeboard. The second cell is a channel basin having a depth range from 0.5 to $0.7 \mathrm{~m}$. The depth of the soil ranges between $20-25 \mathrm{~cm}$ over the liner to support the vegetation and $10 \mathrm{~cm}$ is left as a freeboard. The third cell is $24 \mathrm{~m}^{2}(\mathrm{~W}: \mathrm{L})$ of a rectangular shape basin having a depth of $0.5 \mathrm{~m}$, the soil media depth is $20 \mathrm{~cm}$ and also a $10 \mathrm{~cm}$ is left as a freeboard. Large stones were added near the inlet and the outlet of the basins to spread the wastewater across the width of the wetland. Also, a layer of zeolite gravel media was added to the third cell to provide extra surface area and therefore, increase the effectiveness of the treatments. The fourth cell which is the collection basin was a $2^{\prime} 4 \mathrm{~m}^{2}$ (W: L) of rectangular shape basin. After finishing construction works, the whole wetland was flooded for 2 months to settle the soil and level the bed. The channel bed cell was then dewatered in (but not completely dried) shortly before planting to produce soft, moist soil. The layout of the free water surface wetland was comprised of a deep, open water basin (cell 1) followed by a shallow vegetated channel bed (cell 2) and another shallow, open water basin (cell 3), and a collection basin (cell 4). The first three cells were constructed for the treatment of wastewater and the fourth one was for the collection of the treated effluent (Figure 1). The soil was compacted within all the treatment cells that were also lined to prevent seepage to the groundwater and to maintain the water level in the cells using 600-micron polyethylene layers. Planting was carried out by hand. Planting layout patterns for emergent species include band planting (across the wetland) and parallel to the wetland edge Davis (1995). Cyperus alternifolius was planted inside the channel bed cell. Cyperus alternifolius is known as dwarf palm or umbrella plant or umbrella sedge, which can reach as high as 1-2 $\mathrm{m}$. It is cold-tolerant and can be grown in relatively dry climates. Stems and leaves are likely to withstand $\left(-3^{\circ} \mathrm{C}\right.$ to $\left.-5^{\circ} \mathrm{C}\right)$ frosts while roots may survive down to $\left(-6^{\circ} \mathrm{C}\right.$ to $\left.-8^{\circ} \mathrm{C}\right)$. The plants were brought from one of the neighboring nurseries. For a tall plant such as Cyperus alternifolius, the stem was cut back to approximately $30 \mathrm{~cm}$ to prevent wind-throw. The potted plants were placed in the soil in two rows across the wetland with a distance ranging from 0.75 to $1 \mathrm{~m}$ between the plants and the rows. The total number of plants used in this experiment was 108 plants. When plants were placed in the wetland, enough treated wastewater was added to maintain good saturation of the substrate, but not to flood it. After new growth reached $10-12 \mathrm{~cm}$ in, the treated wastewater level was raised to the recommended operational level. 


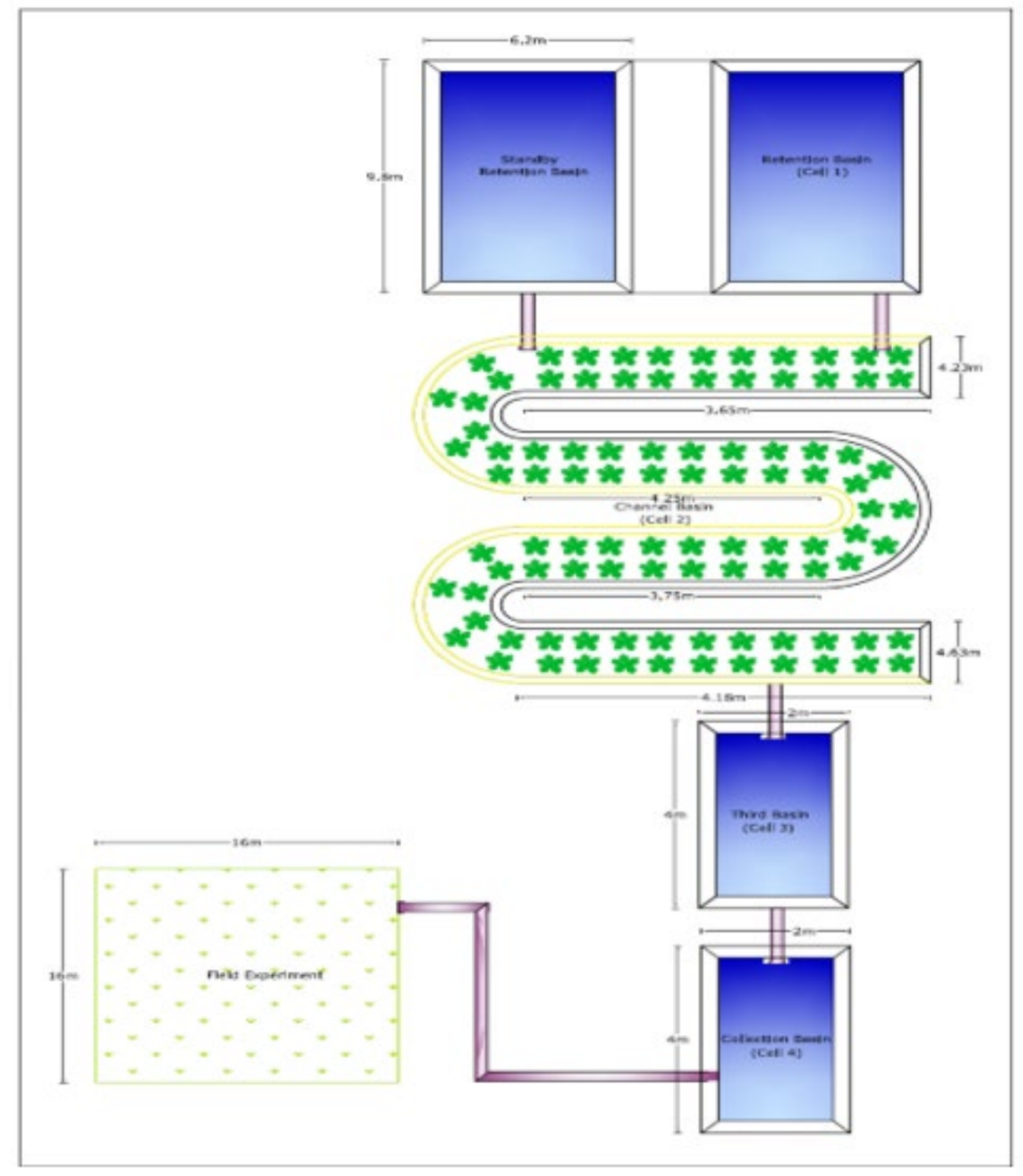

Figure 1 Free Water Surface Constructed Wetland Layout

The volume of the CFWS wetland was estimated at about $80 \mathrm{~m}^{3}$. To simulate different qualities of treated wastewater and study the removal efficiency of different pollutants by the free water surface constructed wetland, the primary treated wastewater effluent was taken from Ramtha treated wastewater plant and mixed with the treated wastewater effluent with different mixtures. Access to treat and primary treated wastewater was established through a pipe network from Ramtha treated wastewater plant to the free water surface wetland. To study the removal efficiency of the free water surface wetland, mixtures were used as experimental factors. The mixture was tested under various hydraulic retention times of 3, 6, 9, and 12 days (Table 1). The experiment was begun with the best quality effluent of $100 \%$ TWW, and then the other effluents with different mixtures were used. 


\begin{tabular}{|c|ccc|}
\hline \multicolumn{4}{|c|}{ Table 1 Types of Wastewater Quality Mixture Tested in the FWS Wetland } \\
\hline $\begin{array}{c}\text { Treatment } \\
\text { (Mixture) }\end{array}$ & $\begin{array}{c}\text { Fully treated } \\
\text { wastewater }\end{array}$ & $\begin{array}{c}\text { Primary treated } \\
\text { wastewater }\end{array}$ & $\begin{array}{c}\text { Legend of mixture used } \\
\text { in the text }\end{array}$ \\
\hline 1 & 100 & 0 & T100 \\
\hline 2 & 75 & 25 & T75, P25 \\
\hline 3 & 50 & 50 & T50, P50 \\
\hline 4 & 25 & 75 & T25, P75
\end{tabular}

\subsection{CHEMICAL ANALYSIS OF WATER}

Inlet and outlet effluent samples were taken for both wetlands according to the sampling schedule and then samples were transferred to the laboratory for analysis. Salinity (ds/m) and turbidity (NTU: nephelometric turbidity unit) were measured directly at the field using portable instruments. $\mathrm{pH}$ and EC were measured at the lab using a $\mathrm{pH}$ meter and conductivity meter in addition to measuring cations and anions. Total suspended solids (TSS) as $\mathrm{mg} / \mathrm{l}$ were determined by filtering the sample and weighing the dry material. Available phosphorus (P) was determined using ammonium molybdate, stannous chloride method, and reading with a spectrophotometer at $720 \mathrm{~nm}$. Total Kjeldahl nitrogen (TKN) was determined by digestion and using the Kjeldahl distillation apparatus. Nitrate $\left(\mathrm{NO}_{3}\right)$ was measured after adding an acid to the sample and then reading it with a spectrophotometer at $206 \mathrm{~nm}$ wavelength. Heavy metals were determined by inductively coupled plasmaatomic emission spectroscopy. Samples were preserved (if needed) for further analysis using the appropriate preservation method specified for each parameter according to the standard methods for the examination of water and APHA (1998).

\subsection{CHEMICAL ANALYSIS OF HARVESTED PLANT}

At the end of each influent mixture treatment shown in Table 1, a plant sample (Cyperus alternifolius) was taken from the channel bed basin for chemical analysis. Two plant samples were selected at each sampling time and separated into rhizomes, roots, stems, and leaves for further chemical analysis. Cyperus alternifolius wetland plant was harvested and biomass weight was measured and recorded. All statistical tests were performed using the SAS software. In all cases, significance was defined by $\mathrm{P}<0.05$. Test for a significant difference in water quality between hydraulic retention times and influent mixtures of the treatment wetland was tested using the mixed procedure analysis of variance (ANOVA) at which time and mixture were factorially arranged. After sampling, plant samples were taken to the laboratory for further cleaning and preparation for future analysis. Samples were then oven-dried and grounded up using Thomas - Wiley mill. Dry ashing was carried out for the determination of potassium $(\mathrm{K})$, calcium $(\mathrm{Ca})$, and heavy metals, while wet ashing was carried out for the determination of sodium ( $\mathrm{Na}$ ). Total Kjeldahl nitrogen (TKN) was determined by digestion and using the Kjeldahl distillation apparatus. All the above parameters were determined using the "Official Methods of Analysis of AOAC International” 18 $8^{\text {th }}$ ed, (2010) Horwitz (2010). Total phosphorus (TP) was determined according to methods of analysis for soil plants and waters Chapman and Pratt (1962). 


\section{RESULTS AND DISCUSSION \\ 3.1. WASTEWATER CHARACTERIZATION}

Results of biological and chemical analysis for both the treated wastewater effluent (TWW) and the primary treated effluent (PE) are listed in Table 2 and Table 3. Both effluents exhibited $\mathrm{pH}$ and $\mathrm{EC}(\mathrm{ds} / \mathrm{m})$ values of $(7.3$ and 1.85$)$ for TWW and (6.5 and 1.89) for PE. Both effluents showed a high concentration of $\mathrm{Na}$ and $\mathrm{Cl}$. Phosphorus $\left(\mathrm{PO}_{4}\right)$, nitrate, and total Kjeldahl nitrogen (TKN) concentration (mg/l) were $(2.6,9.4,74)$ and $(11.3,55,185)$ for TWW and PE, respectively. Results of the biological analysis indicated excellent biological standards for TWW in terms of faecal coliform, $\mathrm{BOD}_{5}$, and COD. The primary treated wastewater exhibited poor biological

standards in terms of the faecal coliform and had a high organic loading related to $\mathrm{BOD}_{5}$ and COD. The quality of wastewater and/or HRT time in FWS constructed wetland significantly affected the pH, EC, TSS, E. coli, P, and turbidity to greater levels and insignificantly affected the concentrations of BOD5, COD, TKN, and N03(data are not presented).

\begin{tabular}{|ccccc|}
\hline \multicolumn{5}{|c|}{ Table $\mathbf{2}$ Chemical Analysis of fully and primary Treated Wastewater Effluents } \\
\hline Treatment & TC/100ml & $\begin{array}{c}\text { Parameters } \\
\text { (FC) E. } \\
\text { coli/100ml }\end{array}$ & $\begin{array}{c}\text { BOD }_{\mathbf{5}} \\
(\mathbf{m g} / \mathbf{l})\end{array}$ & COD (mg/l) \\
\hline TWW & 800 & 40 & 15 & 73 \\
\hline Primary treated & $\geq 1600$ & $160 \times 10^{5}$ & 570 & 831 \\
\hline
\end{tabular}

\begin{tabular}{|c|c|c|c|c|c|c|c|c|c|}
\hline & & $(\mathrm{dS} / \mathrm{m})$ & & & & $\mathrm{meq} / \mathrm{l}$ & & & \\
\hline Effluent & pH & EC & $\mathrm{Ca}$ & Mg & $\mathrm{Na}$ & $\mathbf{K}$ & $\mathrm{Cl}$ & $\mathrm{HCO}_{3}$ & $\mathrm{SO}_{4}$ \\
\hline TWW & 7.3 & 1.8 & 2.2 & 2.7 & 14.9 & 1.2 & 12.5 & 3.5 & 5 \\
\hline \multirow[t]{3}{*}{ Primary treated } & 6.5 & 1.9 & 2.7 & 4.9 & 12.2 & 0.9 & 10 & 6.3 & 4.5 \\
\hline & & \multicolumn{8}{|c|}{ mg/l } \\
\hline & SAR & $\mathrm{Fe}$ & $\mathrm{Cu}$ & Zn & Mn & Cd & $\mathbf{P b}$ & $\mathbf{P}$ & TKN \\
\hline TWW & 9.5 & 0.07 & 0.01 & 0.06 & 0.03 & $<0.002$ & $<0.01$ & 2.6 & 74 \\
\hline Primary treated & 6.3 & 0.34 & 0.01 & 0.07 & 0.03 & $<0.002$ & $<0.01$ & 11.3 & 185 \\
\hline
\end{tabular}

\subsection{CHEMICAL ANALYSIS OF MACROPHYTE}

Emergent macrophytes assimilate nutrients from sediments and also act as nutrient pumps and play a key role in seasonal changes in available $\mathrm{N}, \mathrm{P}$, and $\mathrm{K}$ Vymazal and Kröpfelová (2008), Vymazal and Kröpfelová (2009). Nitrogen is taken up and assimilated by growing plants throughout the growing season. However, the uptake rate varies widely during the growing season. The uptake rates are much higher during the exponential growth phase as compared to the steady-state growth phase. Plants contain 1 to $6 \% \mathrm{~N}$ by weight and absorb $\mathrm{N}$ as both nitrate and ammonium Hernandez and Mitsch (2007). Ammonium is toxic to plant cells and therefore must be assimilated rapidly to amino acids Vymazal and Kröpfelová (2008). Results indicated that the different plant parts show changes in nitrogen content during their various stages of growth. Results of nitrogen $\%$ in the plant were 0.62 to 3.25 . This is very close to other results obtained with respect to nitrogen \% in emergent plants which were 0.93 to 2.56 Kadlec and Wallace (2008). Roots comprise only a minor pool of nitrogen compared to rhizomes and leaves. 
Nitrogen concentration in both roots and leaves was $0.62 \%$ and $2.05 \%$, respectively (Figure 2). The relative importance of plant uptake depends upon the nitrogen loading to the treatment wetland Khanijo (2002). Results indicated that all plant parts were capable of absorbing and accumulating nitrogen with the magnitude of leaves $>$ stem $>$ rhizome $>$ root. The accumulation of nitrogen increased even when the quality of the wetland effluent deteriorates, with leaves accumulating the highest $\mathrm{N}$ concentration $(3.25 \%)$.

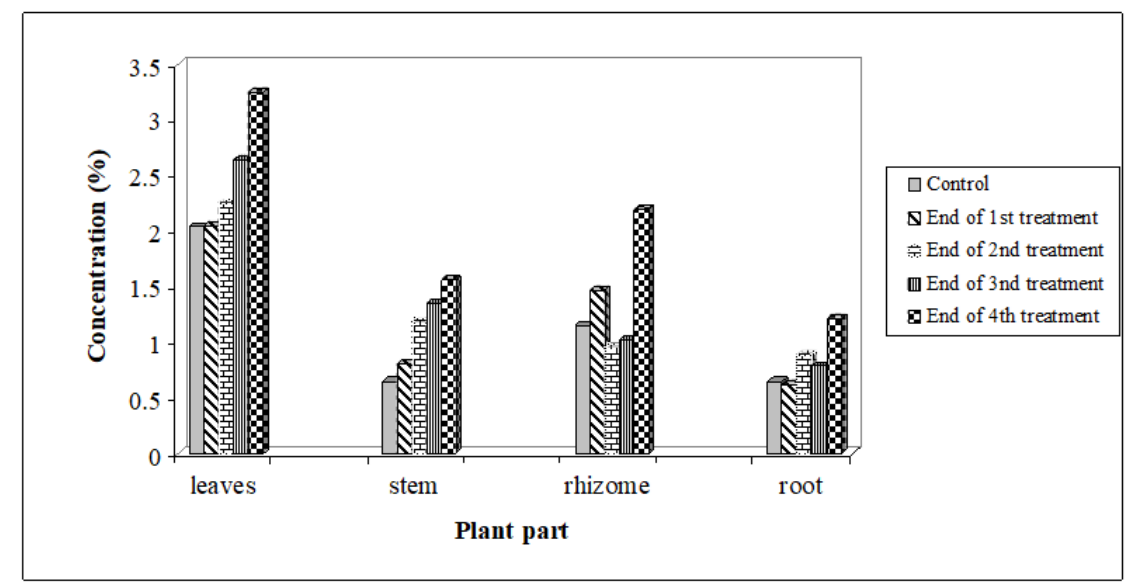

Figure 2 (A)Nitrogen Concentration (\%) in Different Macrophyte Parts under the Different Influent mixtures, (B)

Phosphorus in wetlands occurs as phosphate in organic and inorganic compounds. Free orthophosphate is the only form of phosphorus believed to be utilized directly by algae and macrophytes and thus represents a major link between organic and inorganic phosphorus cycling in wetlands. Phosphorus is incorporated in the tissues of all living organisms and is frequently a limiting factor for vegetative productivity Kadlec and Wallace (2008). Total phosphorus concentration ranged between 0.024 for roots to $0.355 \%$ for rhizomes (Figure 3). Results indicated a pronounced increase in phosphorus concentration as the nutrient status of the wetland was increased, with the rhizome accumulating the highest $\mathrm{P}$ concentration $(0.32 \%)$. This is very close to results observed for the concentration of phosphorus in the plant tissue in constructed wetlands which was in the range of 0.08 to $0.63 \%$ dry matter with an average of $0.25 \%$ DM. Phosphorus storage in the aboveground biomass of emergent macrophytes is usually short-term, with a large amount of $\mathrm{P}$ being released during the decomposition of litter. The aboveground portions of macrophyte return $\mathrm{P}$ to the water, while belowground portions return $\mathrm{P}$ to the soil. Some radio studies outlined that phosphorus uptake by microbiota occurs on a time scale of less than 1 hour. However, more than $90 \%$ was released within the next 6 hours Vymazal and Kröpfelová (2008), Zhu et al. (2003). 


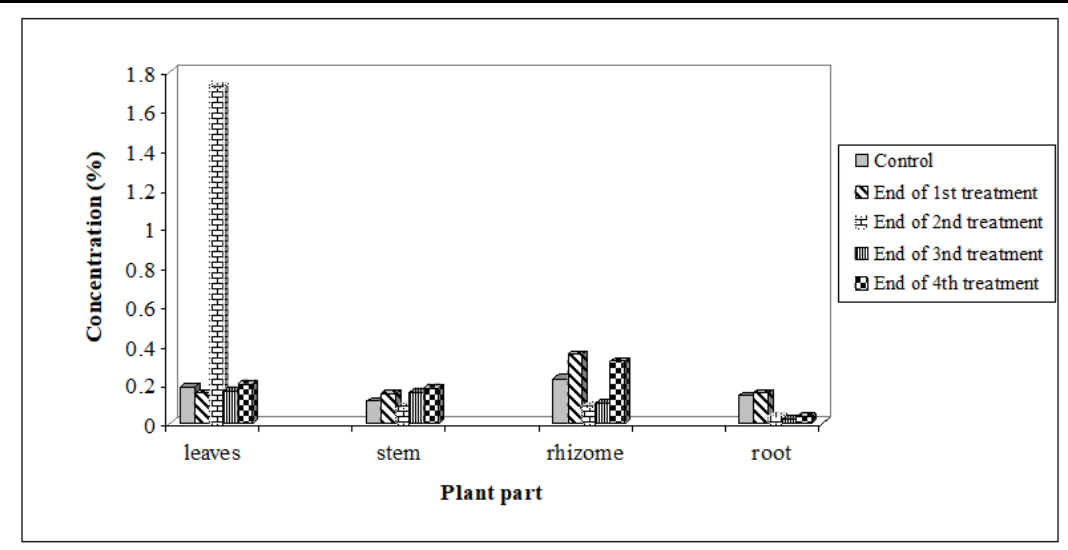

Figure 3 Total Phosphorus Concentration (\%) in Different Macrophyte Parts under the Different Influent mixtures

Potassium has an elevated concentration in wastewater, but wetland systems are commonly used for its control Batool and Saleh (2020), Kadlec and Wallace (2008). It is highly mobile because it is more exchangeable from wetland soils than nitrogen and phosphorus. Potassium is essential for carbohydrate synthesis and the transfer of sugars. It regulates the water status of plants and activates several enzyme systems. Potassium typically comprises about $2.6 \%$ of the dry weight of wetland plants. Results indicated a pronounced increase in potassium concentration as the nutrient status of the wetland was increased, with the rhizome and stem accumulating the highest amount of 4.37 and $5.03 \%$ (Figure 4 ).

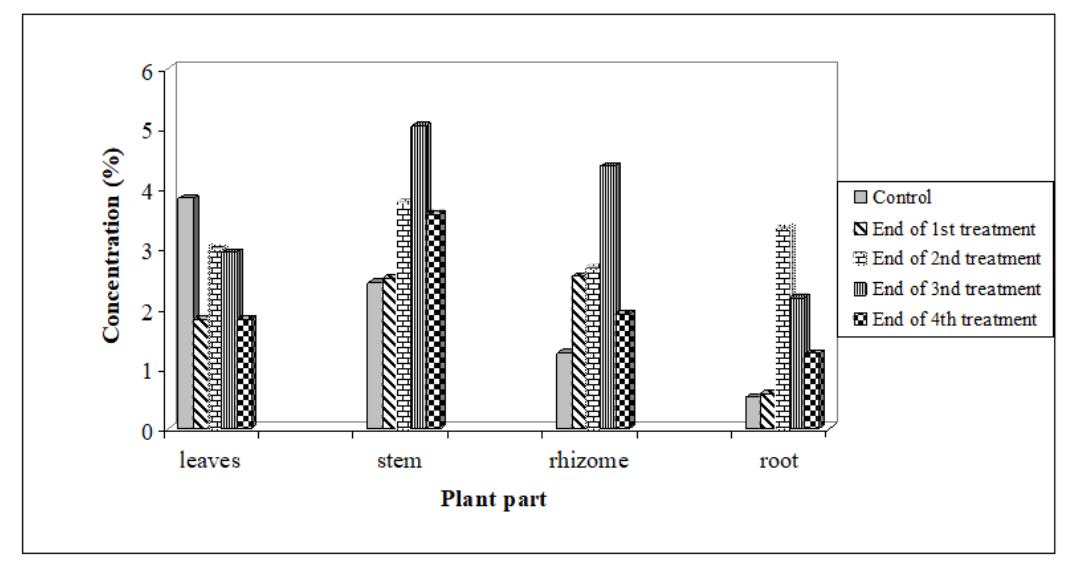

Figure 4 Potassium Concentration (\%) in Different Macrophyte Parts under the Different Influent mixtures

Metals in the soluble and exchangeable form are considered readily mobilized and available to plants. Macrophytes have been shown to play important roles in wetland biogeochemistry through their active and passive circulation of elements Khanijo (2002), Weis and Weis (2004). Manganese is considered one of the essential metals for the growth of plants. Manganese is vital to plant photosynthesis and is used as an enzyme cofactor for respiration and nitrogen metabolism by plants. Manganese occurs in a number of valency states, the existence of a particular valency state depending, to a large extent, on the $\mathrm{pH}$ and redox potential of the system in the normal $\mathrm{pH}$ range $(\mathrm{pH}$ 6-9) of natural waters, soluble divalent $\mathrm{Mn}$ consists of $\mathrm{Mn}^{+2}$ and $\mathrm{MnOH}$. Results indicated a sudden reduction in manganese concentration under the second and third mixture without known reasons. Results from the research indicated that some of the $\mathrm{Mn}$ is accumulated in the roots 308.72 
ppm but also a high amount was translocated to the leaves as $802.66 \mathrm{ppm}$ to be used by the plant (Figure 5).

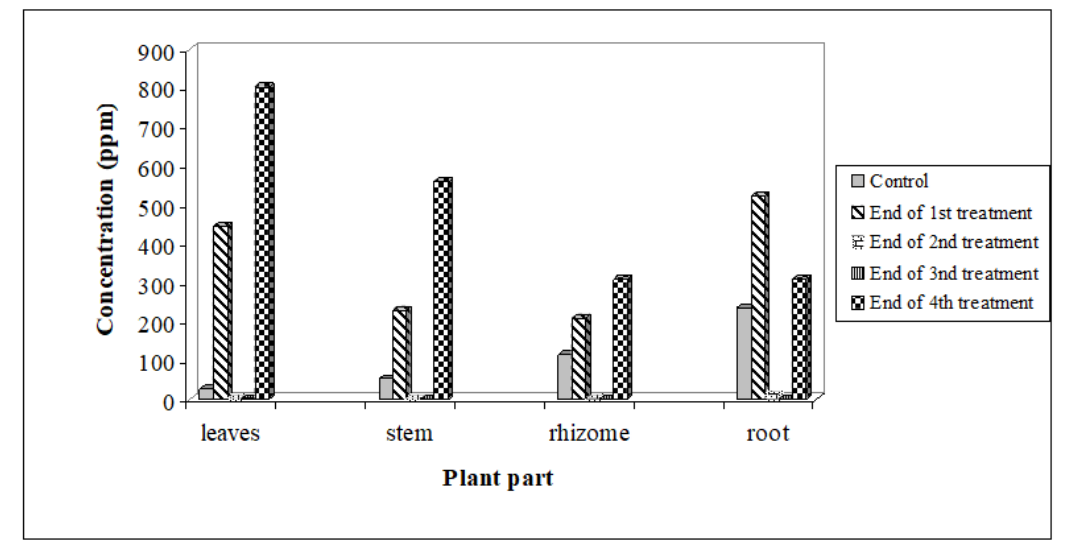

Figure 5 Manganese Concentration (ppm) in Different Macrophyte Parts under the Different Influent mixtures

Results from our experiment showed that roots (62.3\%) and rhizomes (63.5\%) are the main sinks for zinc followed by leaves (35.4\%) and stems (25.6\%) (Figure 6). Zinc is considered one of the essential metals for the growth of plants and is considered to be toxic at relatively low concentrations. As with most trace elements, the concentration of $\mathrm{Zn}^{+2}$ in plants at which toxicity appears is not well known Drakatos et al. (2000), Weis and Weis (2004). Results indicated that the plant was able to accumulate zinc within the root and the rhizome. Weis and Weis (2004) concluded that there have been conflicting reports as to whether the presence of iron plaque reduces or increases the uptake of metals like zinc by the plants. Because of the high binding capacity for metallic micronutrients by soil particles, plants have evolved several strategies for increasing their soil bioavailability. These strategies include the production of metal-chelating compounds which are synthesized in response to iron and possibly zinc deficiencies.

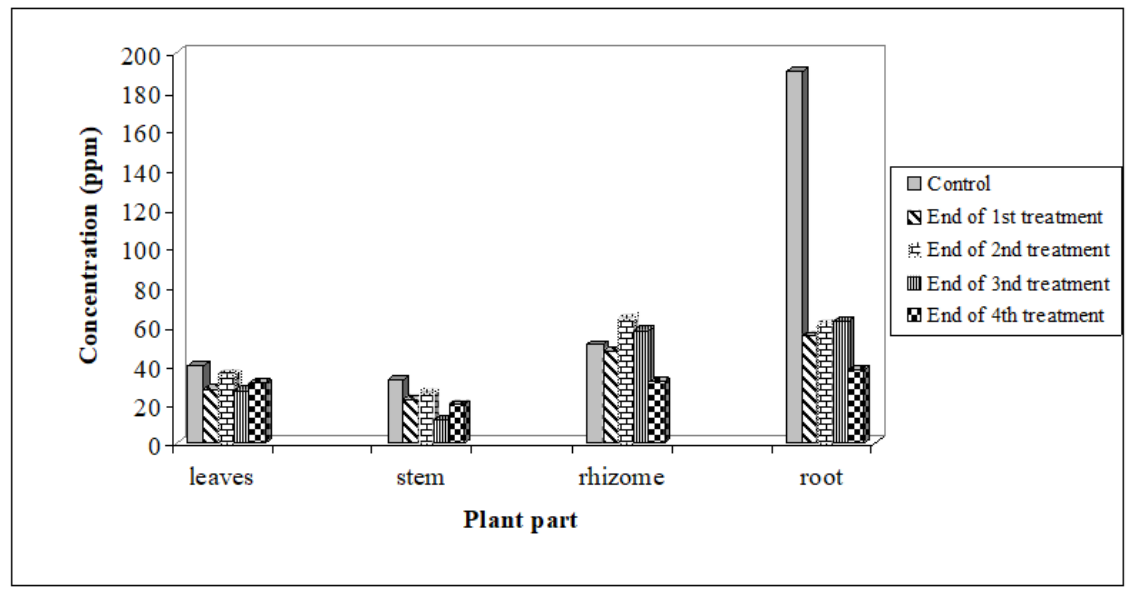

Figure 6 Zinc Concentration (ppm) in Different Macrophyte Parts under the Different Influent mixtures

\section{CONCLUSION}

Vegetation plays a significant role in constructed wetlands, especially on nitrogen and phosphorus removal. Higher accumulation of nitrogen $\mathrm{N}$ was detected 
in the plant's parts in an order magnitude of leaves $>$ stem $>$ rhizome $>$ root. Pronounced increase in potassium $\mathrm{K}$ concentration at the rhizome and stem was detected, while high amount of manganese $\mathrm{Mn}$ was accumulated in leaves. Roots and rhizomes were the main sinks for zinc Zn and phosphorus P.

\section{ACKNOWLEDGMENTS}

The authors are very thankful to Middle East Regional Cooperation program US-AID MERC for the financial support and to all the associated personnel in any reference that contributed /to this research

\section{REFERENCES}

APHA, A. P. H. A. (1998). Standard methods for the examination of water and wastewater (Vol. 2). American Public Health Association.

Batool, A., \& Saleh, T. A. (2020). Removal of toxic metals from wastewater in constructed wetlands as à green technology; catalyst role of substrates and chelators. Ecotoxicology environmental safety, 189, 109924. Retrieved from https://doi.org/10.1016/j.ecoenv.2019.109924

Brix, H. (2003). Plants used in constructed wetlands and their functions. 1st International Seminar on the use of Aquatic Macrophytes for Wastewater Treatment in Constructed Wetlands, edit. Dias V., Vymazal J. Lisboa, Portugal, Retrieved from https://www.researchgate.net/profile/HansBrix/publication/230563384_Plants_used_in_constructed_wetlands_and_t heir_functions/links/00b4952c01bcfede04000000/Plants-used-inconstructed-wetlands-and-their-functions.pdf

Chapman, H. D., \& Pratt, P. F. J. S. S. (1962). Methods of analysis for soils, plants and waters. 93(1), 68. Retrieved from https://doi.org/10.1097/00010694196201000-00015

Crites, R. W. (1994). Design Criteria and Practice for Constructed Wetlands. Water $\begin{array}{llll}\text { Science and } & \text { Technology, } & \text { 1-6. }\end{array}$ https://doi.org/10.2166/wst.1994.0144 Water Science and Technology Retrieved from https://doi.org/10.2166/wst.1994.0144

Davis, L. (1995). A handbook of constructed wetlands : à guide to creating wetlands for : agricultural wastewater, domestic wastewater, coal mine drainage, stormwater in the Mid-Atlantic Region.

Drakatos, P., Kalavrouziotis, J., \& Drakatos, S. (2000). Synergism of Cu and Zn in plants irrigated with processed wastewater. Land Contamination Reclamation, 8(3), 201-207. Retrieved from https://www.cabdirect.org/cabdirect/abstract/20001916091

Hammer, D. A. (2020). Constructed wetlands for wastewater treatment : municipal, industrial and agricultural. CRC Press. Retrieved from https://doi.org/10.1201/9781003069850

Healy, M. G., Newell, J., \& Rodgers, M. (2007). HARVESTING EFFECTS ON BIOMASS AND NUTRIENT RETENTION IN PHRAGMITES AUSTRALIS IN A FREEWATER SURFACE CONSTRUCTED WETLAND IN WESTERN IRELAND. Biology and Environment: Proceedings of the Royal Irish Academy, 107B(3), 139-145. Retrieved from https://doi.org/10.1353/bae.2007.0009

Hernandez, M. E., \& Mitsch, W. (2007). Denitrification in created riverine wetlands : Influence of hydrology and season. Ecological Engineering, 30(1), 78-88. Retrieved from https://doi.org/10.1016/j.ecoleng.2007.01.015 
Horwitz, W. (2010). Official methods of analysis of AOAC International. Volume I, agricultural chemicals, contaminants, drugs/edited by William Horwitz. Gaithersburg (Maryland) : AOAC International, 1997.

Kadlec, R. H., \& Wallace, S. (2008). Treatment wetlands. CRC press. Retrieved from https://doi.org/10.1201/9781420012514

Khanijo, I. (2002). Nutrient removal from waste water by wetland system. Wetlands, 10, 1-12. Retrieved from https://www.engineering.iastate.edu/ tge/ce421-521/ishadeep.pdf

Kyambadde, J., Kansiime, F., Gumaelius, L., \& Dalhammar, G. (2004). A comparative study of Cyperus papyrus and Miscanthidium violaceum-based constructed wetlands for wastewater treatment in a tropical climate. Water Research, 38(2), 475-485. Retrieved from https://doi.org/10.1016/j.watres.2003.10.008

Stottmeister, U., Wießner, A., Kuschk, P., Kappelmeyer, U., Kästner, M., Bederski, O., . .. Moormann, H. (2003). Effects of plants and microorganisms in constructed wetlands for wastewater treatment. Biotechnology Advances, 22(1), 93117. Retrieved from https://doi.org/10.1016/j.biotechadv.2003.08.010

Sundaravadivel, M., Vigneswaran, S., \& technology. (2001). Constructed wetlands for wastewater treatment. Critical reviews in environmental science technology 31(4), 351-409. Retrieved from https://doi.org/10.1080/20016491089253

Tanner, C. C. (1996). Plants for constructed wetland treatment systems - A comparison of the growth and nutrient uptake of eight emergent species. Ecological Engineering, 7(1), 59-83. Retrieved from https://doi.org/10.1016/0925-8574(95)00066-6

Vymazal, J. (2001). Types of constructed wetland for wastewater treatment: Their potential for nutrient removal. The Netherlands: Backhuys Publishers.

Vymazal, J., \& Kröpfelová, L. (2008). Wastewater treatment in constructed wetlands with horizontal sub-surface flow (Vol. 14). Springer science \& business media. Retrieved from https://doi.org/10.1007/978-1-4020-8580-2

Vymazal, J., \& Kröpfelová, L. (2009). Removal of nitrogen in constructed wetlands with horizontal sub-sureface flow : à review. Wetlands, 29(4), 1114-1124. Retrieved from https://doi.org/10.1672/08-216.1

Vymazal, J., Greenway, M., Tonderski, K., Brix, H., \& Mander, Ü. (2006). Constructed Wetlands for Wastewater Treatment. In J. T. A. Verhoeven, B. Beltman, R. Bobbink, \& D. F. Whigham (Eds.), Wetlands and Natural Resource Management (pp. 69-96). Springer Berlin Heidelberg. Retrieved from https://doi.org/10.1007/978-3-540-33187-2_5

Weis, J. S., \& Weis, P. (2004). Metal uptake, transport and release by wetland plants : implications for phytoremediation and restoration. Environment International, 30(5), 685-700. Retrieved from https://doi.org/10.1016/j.envint.2003.11.002

Zhu, T., Maehlum, T., Jenssen, P. D., \& Krogstad, T. (2003). Phosphorus sorption characteristics of a light-weight aggregate. Water Science and Technology, 48(5), 93-100. https://doi.org/10.2166/wst.2003.0290 Water Science and Technology Retrieved from https://doi.org/10.2166/wst.2003.0290 